\title{
EFFECT OF LIGHT AND MEDIA UPON GROWTH AND MELANIN FORMATION IN CLADOSPORIUM MANSONI
}

\author{
by
}

A. S. Sussman, Yamuna Lingappa \& I. A. Bernstein

Departments of Botany and Dermatology, University of Michigan, Ann Arbor, Michigan, U.S.A.)

\section{II.1963}

(with 3 figs.)

Cladosporium mansoni is a human pathogen that is highly pleomorphic and resembles Aureobasidium in the formation of yeastlike cells that often are dark in the aggregate. In fact, it has been stated that the organism with which Aureobasidium is most often confused is Cladosporium (Cooke, 1962). Therefore, recent studies of the carbon nutrition and formation of melanin in Aureobasidium (LiNGAPPA, et al., 1963) were extended to include Cladosporium mansoni in order that a comparison could be made of these aspects of the physiology of the two organisms.

\section{Materials AND Methods}

The cultures of Cladosporium mansoni used in this work were obtained from the American Type Culture Collection (ATC \#762) and were maintained on potato dextrose and nutrient agars. Defined media \#1 and \#2, whose composition is provided in LINGAPPA, et al., (1963), were used in nutritional experiments along with the Neurospora "minimal" medium (RYan, 1950). All undefined media used were the product of the Difco Co., Detroit, Michigan.

Techniques for harvesting cells and determining growth are as described previously (LINGAPPA, et al., 1963) as are the methods used in the extraction and analysis of melanin.

\section{RESULTS}

When C. mansoni is grown on defined medium $\# 1$, containing asparagine, the results provided in Table I are obtained. Trehalose is the best carbon source of those tried and sucrose, maltose, all of 
the monosaccharides and dextrine also support good growth. By contrast, starch and lactose support only sparse growth, whereas inulin and chitin are not used at all. Melanin, by the criteria used in the previous paper, is formed in cells grown on the good carbon sources, except for those on fructose. The most abundant pigmentation is found in cultures grown on trehalose. Furthermore, extracellular granules never are formed in any cultures grown on defined medium \#1 with asparagine.

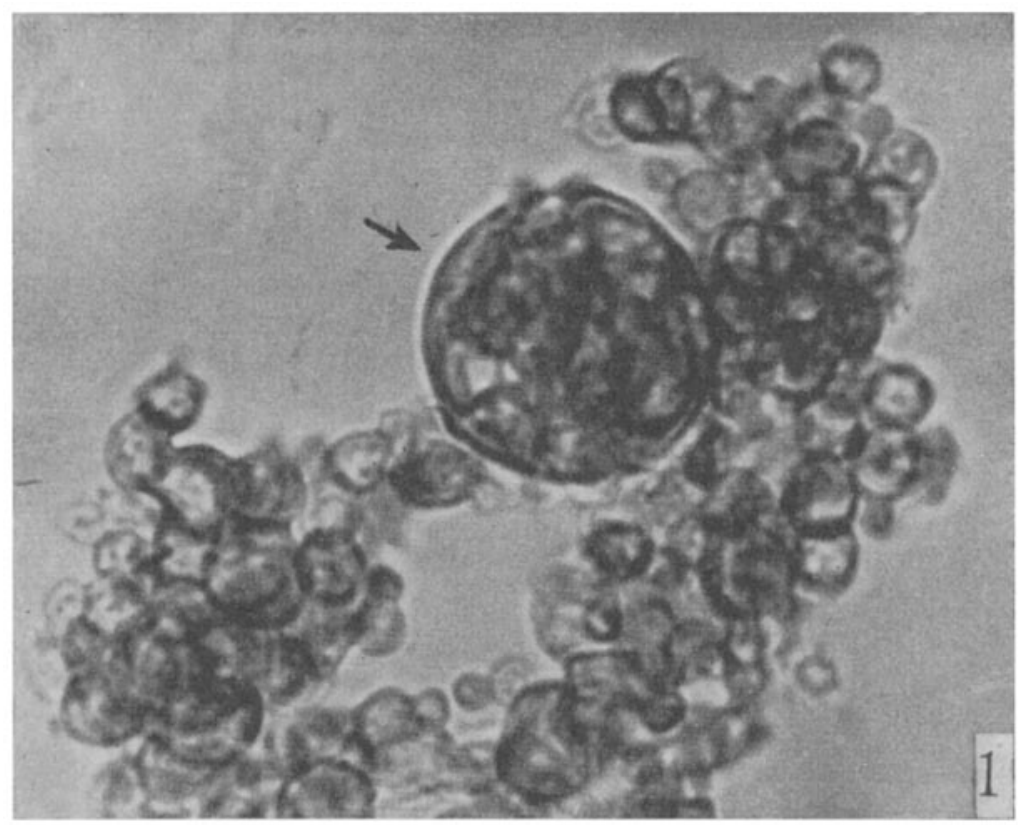

Fig. 1. Appearance of Cladosporizm mansoni grown for two weeks in defined medium $\not 2$ in the dark. Arrow indicates a "giant" cell. Magnification - approx. 2,000x.

The pigment from cells of Cladosporium was extracted and absorption spectra obtained as shown in figure 3 . Straight lines were obtained between 400 and $600 \mathrm{~m} \mu$ with slopes of -0.0029 (in glucose), -0.0025 (in dextrine) and -0.0022 (in sucrose).

Other defined media were used with $C$. mansoni, including the Neurospora "minimal", and defined medium $\# 2$. In contrast to the results obtained with Aureobasidium the data in Table II show that differences between light- and dark-grown cultures can be observed on Defined medium $\# 2$ with Cladosporium. Abundant mycelium is formed by the organism on this medium and the cells are thin-walled and dark in color (Figure 2). Melanin is formed by cells in such cultures but no extracellular granules are found. 


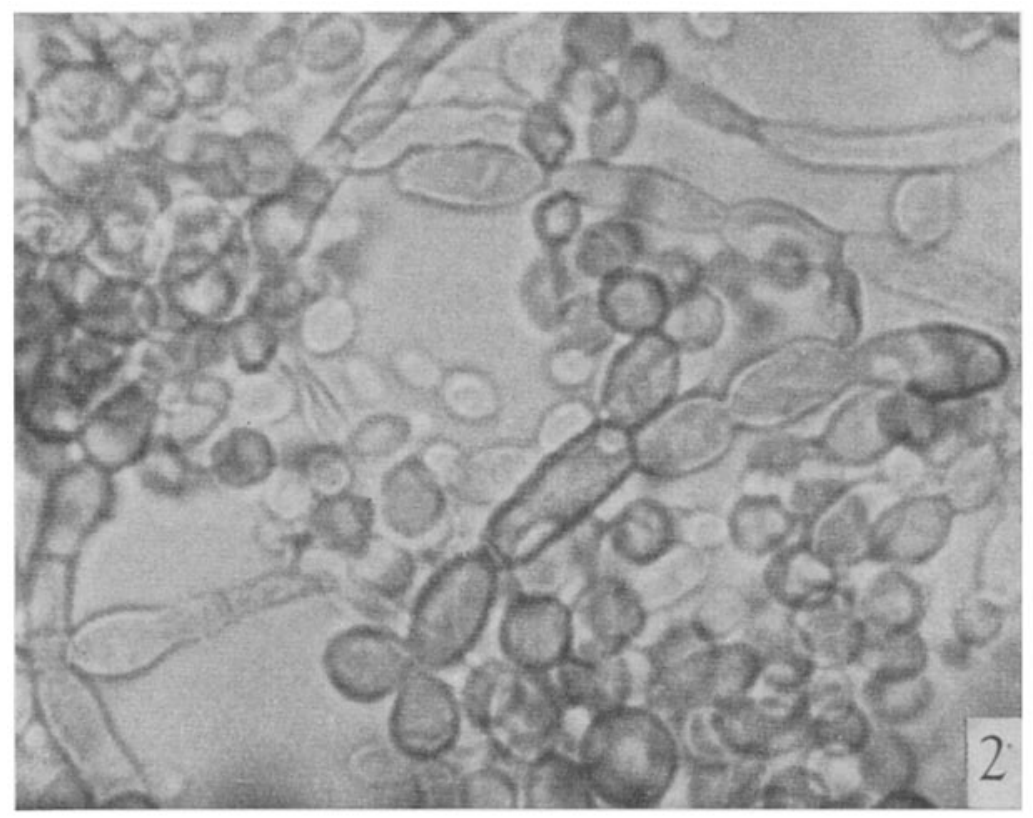

Fig. 2. Appearance of Cladosporium mansoni grown for two weeks in defined medium $\# 2$ in the light. Note the large amount of mycelium present under these conditions. Magnification - approx. 2,000 $\times$.

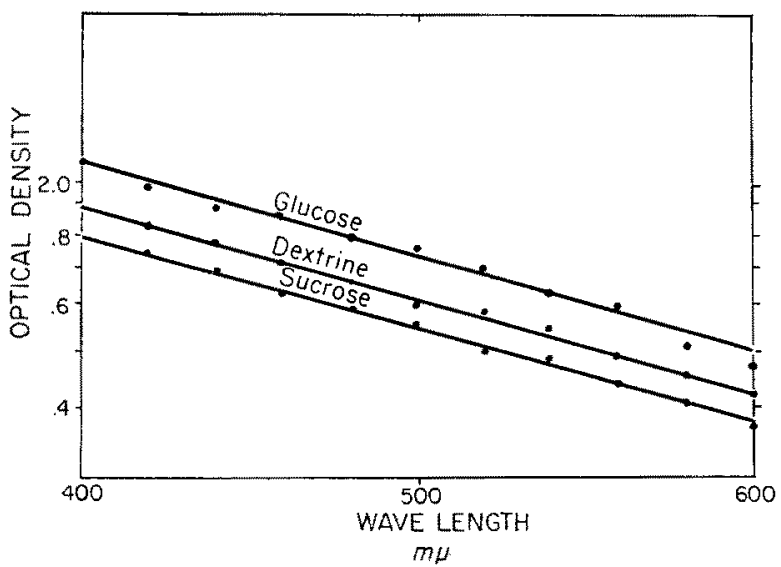

Fig. 3. Absorption spectra of alkaline extracts of cells of Cladosporium mansoni grown on basal medium $\neq 1$ with $2 \%$ dextrine. Cultures were maintained in the light for 14: days at $21^{\circ} \mathrm{C}$ and extracts were prepared and observed as described before in LINGAPPA et al., 1963. 
TABLE I.

Growth of C. mansoni on defined medium \#1, containing $2 \%$ carbohydrate. Cultures were maintained in the light on a rotary shaker for 14 days.

\begin{tabular}{|c|c|c|c|c|}
\hline $\begin{array}{l}\text { Carbo- } \\
\text { hydrate }\end{array}$ & $\begin{array}{l}\text { Dry wt. of } \\
\text { growth } \\
\text { g }\end{array}$ & $\begin{array}{l}\text { Wet wt. of } \\
\text { Melanin } \\
\mathrm{g}\end{array}$ & $\begin{array}{l}\text { Color of } \\
\text { culture }\end{array}$ & Remarks \\
\hline Dextrine & .1524 & .0125 & $\begin{array}{l}\text { Greenish- } \\
\text { black }\end{array}$ & $\begin{array}{l}\text { Mycelium scanty, no } \\
\text { extracellular granules, } \\
\text { cells small, thin-walled, } \\
\text { gray in aggregation. }\end{array}$ \\
\hline Starch & .095 & nil & no color & $\begin{array}{l}\text { Starch granules in- } \\
\text { completely used, cell } \\
\text { yeast-like with a few } \\
\text { brown cells, no myce- } \\
\text { lium. }\end{array}$ \\
\hline Inulin & nil & nil & - & No growth \\
\hline Chitin & nil & nil & - & No growth \\
\hline Sucrose & .1139 & .010 & Light green & $\begin{array}{l}\text { Cells yeast-like, small, } \\
\text { colorless, or greenish; } \\
\text { supernatant culture } \\
\text { fluid light green. }\end{array}$ \\
\hline Lactose & .0318 & nil & Colorless & $\begin{array}{l}\text { No mycelium, cells } \\
\text { yeastlike, and color- } \\
\text { less. }\end{array}$ \\
\hline Maltose & .1371 & .019 & dark-brown & $\begin{array}{l}\text { Cells yeast-like, thin- } \\
\text { walled and light brown } \\
\text { in aggregation; no my- } \\
\text { celium; culture fluid } \\
\text { brown. }\end{array}$ \\
\hline Trehalose & .2126 & .0325 & brown & $\begin{array}{l}\text { Cells were dark and } \\
\text { supernatant; color- } \\
\text { less) no mycelium. }\end{array}$ \\
\hline Glucose & .1185 & .0198 & greenish & $\begin{array}{l}\text { Scanty mycelium, } \\
\text { yeast-like cells which } \\
\text { are greenish in aggre- } \\
\text { gation. }\end{array}$ \\
\hline Fructose & .1391 & nil & buff color & $\begin{array}{l}\text { No mycelium; cells } \\
\text { yeast-like; colorless. }\end{array}$ \\
\hline Galactose & .112 & .009 & $\begin{array}{l}\text { light } \\
\text { brown }\end{array}$ & $\begin{array}{l}\text { No mycelium, cells } \\
\text { dark in aggregate; me- } \\
\text { dium not colored. }\end{array}$ \\
\hline
\end{tabular}

Growth on defined medium $\# 2$ in the light was similar to that in Neurospora "minimal" medium in that considerable mycelium was found (Table II). Morphological similarities between the cells also exist in that they are of similar size and appearance, except that those in defined medium $\# 2$ are more uniform in both these respects.

Cultures grown in the dark on defined medium $\# 2$ revealed that light strongly influenced development in this medium. Such an effect is revealed in Table III where the morphology and size of cells of Cladosporium grown in the light and dark are compared. Whereas light-grown cells form abundant mycelium on defined medium $\# 2$, 
those grown in the dark are almost devoid of such aggregates. Moreover, "giant" cells, which sometimes reach over $20 \mu$ in diameter, are formed in the dark but are never found in the light. As can be seen in figure 1, partitions often appear in such "giant" cells,

TABLE II.

Effect of defined media upon growth and melanin formation by Cladosporium mansoni. Neurospora" "minimal" medium and defined medium 72 were used and results are trom cultures maintained in the light at $21^{\circ} \mathrm{C}$, for 14 days.

\begin{tabular}{lll}
\hline Carbohydrate & Dry wt. of & Wet wt. of Color of medium Other remarks \\
& cells in $\mathrm{g}$ & melanin in \\
& $45 \mathrm{ml}$ & $45 \mathrm{ml}$ \\
& culture & culture
\end{tabular}

Netwospora
"minimal":
Dextrine

Glucose

Defined medium

\#2:

Dextrine \&

$$
.2 \mathrm{~g} / 1
$$

$\mathrm{NH}_{4} \mathrm{NO}_{3} \ldots$

Dark green

$2 \mathrm{~g} \mathrm{NH}_{4} \mathrm{NO}_{3}$

Glucose \&

$.2 \mathrm{~g} / \mathrm{ml}$

$\mathrm{NH}_{4} \mathrm{NO}_{3} \ldots$

$$
.0272
$$

.06

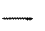

.0205
Color appeared on the $3 x d$ day and became dark in one week.

Same as above
Abundant mycelium; cells dark but thin-walled and $2-8 \mu$ in size. No granules. Same as above.

TABLE III,

Effect of light upon the size and types of cells formed by Cladosporium mansoni in defined medium $\# 2$ containing $2 \%$ dextrose and $0.2 \% \mathrm{NH}_{4} \mathrm{NO}_{3}$. Cultures were maintained for 14 days at $21^{\circ} \mathrm{C}$.

Light-grown

Dark-grown

Type of Cells

Abundant mycelium, cells

Very little mycelium; many of which are uniform in size.

"giant" cells. (Fig. 1)

(Fig. 2 )

Average size

$3 \times 5 \mu$

$13 \times 14 \mu$

(100 cells)

Size range

(100 cells)

$3 \times 7 \mu-5 \times 8 \mu$

$8 \times 9 \mu-20 \times 22 \mu$ extracellular granules; cells uniform; $4 \mu$ in diameter.

Same as above.

Same as above. 
suggesting the cleavage of protoplasm within a sporangium. However, the discharge of the contents of such cells was never observed so that their role is obscure.

Light was shown to influence the growth of Cladosporium on other media as well, for cultures grown on slants of nutrient, potato dextrose and corn meal agars, are very black after incubation in the light at the end of one week at $21^{\circ} \mathrm{C}$. By contrast, those grown in the dark on these media require three weeks to turn black and differences in the morphology of cells also are observable.

TABLE IV.

Cladosporium mansoni in defined medium $\# 1$, containing $0.2 \mathrm{~g} \mathrm{NH}_{4} \mathrm{NO}_{3}$ instead of asparagine. Cultures grown in the light for 14 days at $21^{\circ} \mathrm{C}$,

\begin{tabular}{|c|c|c|c|c|}
\hline Carbohydrate & & Melanin wet & Culture color & Other remarks \\
\hline Dextrine & .2433 & .2576 & Dark green & $\begin{array}{l}\text { Cells uniform, yeast- } \\
\text { like and extracellular } \\
\text { granules present }\end{array}$ \\
\hline Glucose & .1956 & .2035 & Dark green & $\begin{array}{l}\text { Same as above ex- } \\
\text { cept granular; extra- } \\
\text { cellular granules } \\
\text { were lacking. }\end{array}$ \\
\hline
\end{tabular}

Extracellular granules were not produced by Cladosporium mansoni in any of the media used above. However, it was found possible to induce their formation by using a modification of defined medium \#1 in which $0.2 \mathrm{~g}$ per liter of $\mathrm{NH}_{4} \mathrm{NO}_{3}$ was used instead of asparagine. As the data in Table IV reveal, extracellular granules, of the size and color produced by Aureobasidium, are formed by Cladosporinm in the above medium when dextrine is the carbon source. Light has no effect upon cell morphology or the formation of extracellular granules when defined medium \#1, with $\mathrm{NH}_{4} \mathrm{NO}_{3}$, is used.

\section{Discussion}

On the basis of their solubility, and the slope of the absorption spectra of basic solutions, the melanins from Aureobasidium pullulans and Cladosporium mansoni are similar. Thus, the slopes for the melanins from $A$. pullulans grown on sucrose, glucose and dextrine are $-0.0018,-0.0017$ and -0.0016 respectively (LINGAPPA et al., 1963), as compared with $-0.0022,-0.0029$ and -0.0025 for the melanins from $C$. mansoni grown on the same media. On the other hand, these tests are non-specific and more analyses are necessary before a comparison of these melanins is possible in chemical terms.

Extracellular granules of the kind reported for Aureobasidium are formed by Cladosporium when dextrine is the carbon source in 
defined medium \#1. However, such granules are formed only when $\mathrm{NH}_{4} \mathrm{NO}_{3}$ is the nitrogen source, in contrast to Aureobasidium which requires asparagine for their formation.

Among the differences between Cladosporium and Aureobasidium that are worth noting is that concerned with trehalose metabolism. Thus, dark brown cells form when $C$. mansoni is grown on trehalose, whereas uncolored yeast-like cells form in the other sugars in defined medium $\# 1$. By contrast, trehalose induces the formation of colorless cells of Aureobasidium whereas dark thick-walled cells form in the other good sources of carbon.

TABLE V.

Physiological differences between Auveobasidium pullulans and Cladosporinm mansoni.

Physiological Property $\ldots$ Auveobasidium pullulans* Cladosporium mansoni

Effectiveness of carbohy-
drates in supporting
growth:
$\quad$ good sources

poor sources

Medium in which extracellular granules form . . . .

Color of culture in light in defined medium \#1 with trehalose...

Color of cells in above medium in light . . .

Light effects in:

Neurospora "minimal medium". . . nutrient agar ...

defined medium $\# \mathbf{1} \ldots$ defined medium $\# 2$..

\begin{abstract}
dextrine $>$ starch $>$ sucrose $>$ maltose $>$ glucose $>$ trehalose $>$ pectin fructose $>$ galactose inulin $>$ lactose
\end{abstract}

defined medium $\# \mathbf{1}$, dextrine with asparagine.

colorless

colorless

$\begin{array}{ll}+ & - \\ + & + \\ + & +\end{array}$

brown

brown

trehalose $>$ dextrine $>$ fructose $>$ maltose $>$ glucose $>$ sucrose $>$ galactose starch > lactose, no growth in inulin.

same, but with $\mathrm{NH}_{4} \mathrm{NO}_{3}$ as nit. source

$$
\frac{+}{+}
$$

*Data taken from LingapPa et al., 1963.

Light influences these two organisms differently as well in that the growth of Aureobasidium is affected in defined medium \#1 and in Neurospora ,minimal" medium. On the other hand, no light effects are discernible in Cladosporium on these media; instead, light effects are demonstrable on defined medium $\# 2$ and on nutrient agar. Conidial formation by Cladosporium carpophilum is reported to be stimulated by light (ScHwEIzER, 1958) but we know of no other effects of light upon members of this genus. 
The data in Table $\mathrm{V}$ summarize the differences between $C$. mansoni and $A$. pullulans with respect to the experiments just discussed. Not only do these organisms differ in their ability to grow on certain carbohydrates, but the formation of pigment is affected differently by light and various media. We recognize that the great variability of these fungi, and their pleomorphism, restrict the generality of comparisons of only single strains. However, the physiological properties used in the present studies may lead to the development of reliable criteria for distinguishing between the black yeasts when these studies are extended.

\section{Summary}

Cladosporium mansoni (ATC \#762) was shown to grow best on trehalose although a number of other carbohydrates are good carbon sources. On the other hand, starch, lactose and inulin support growth poorly, or not at all. In certain media light induces the formation of abundant mycelium whose cells are of average size; in the dark, little or no mycelium is formed and many "giant" cells appear. The pigment of $C$. manson $i$ was extracted and shown to have properties in common with those of melanins of other fungi. Extracellular granules, resembling melanin, appear in a defined medium containing dextrine and ammonium nitrate. A comparison between the response of Cladosporium mansoni and Aureobasidium pullulans to light and carbon sources shows several points of divergence.

\section{Acknowledgements}

We are indebted to the Phoenix Project of the University of Michigan for providing funds to support this research.

\section{References}

Cooke, W. B. (1962) An ecological life-history of Aureobasidium pullulans. Unpublished manuscript.

Lingappa, Yamuna, Sussman, A. S. \& Bernstein, I. (1963) Effect of light and media upon growth and melanin formation in Aureobasidium pullulans (De By.) Arn. (= Pullularia pullulans). Mycopathol. et Mycol. App. 20, 109-128.

RyAn, F. T. (1950) Selected methods of Neurospora genetics. In Methods in Medical Research, Vol. 3. ed. Gerard, R. pp. 51-75. Chicago, U.S.A.: Year Book Publisbers, Inc.

Schweizer, H. (1958) Kulturansprüche des Kirschen- und des Pfirsichscherferregers [Fusicladium cerasi (RABH.) SAcc. = Venturia cerasi A. D. und Cladosporamm caspophilum ]. THüm] auf künstlichen Nährböden. Arch. Mikrobiol. 30, 335-354. 